\title{
IN MEMORIAM MONSENHOR CELSO TAVARES DA SILVA
}

Já depois de ter sido entregue na tipografia todo o original destinado ao volume de homenagem a Monsenhor Celso Tavares da Silva, foi a Diocese de Viseu, e todos os que o admirávamos e éramos seus amigos, dolorosmente surpreendida com o falecimento de Monsenhor Celso, ocorrido na tarde do dia 7 de Junho, em Lisboa, mais precisamente no Hospital de Santa Maria, aonde tinha sido internado dias antes para ser submetido a melindrosa operação cirúrgica.

Embora nenhum dos que tanto o admirávamos ignorasse os riscos da intervenção a que tinha de sujeitar-se, todos acalentávamos a esperança de que o nosso querido Amigo ultrapassasse mais esta prova com que foi confrontado no ano em que tinha completado o seu $800^{\circ}$ aniversário.

Não foi, infelizmente, o que aconteceu e Deus chamou à Sua presença Aquele que, durante mais de cinquenta anos, $O$ serviu com inexcedível zelo e dedicação, numa doação permanente, que só possuem os homens que fazem das suas vidas uma contínua entrega a Deus e aos outros.

A Diocese de Viseu e a Universidade Católica Portuguesa estão mais pobres com a partida de Monsenhor Celso, mas a sua memória permanecerá sempre entre nós.

A nossa condição humana sente dolorosamente a sua ausência, mas a nossa fé suplanta esse legítimo sentimento e leva-nos a proferir, no recolhimento sentido com que evocamos a sua memória, a expressão tão cheia de significado:

Monsenhor Celso, ora pro nobis!

Nicolau Vasconcelos Raposo 